\title{
ICT Policies of the European Union: From an Information Society to eEurope. Trends and visions
}

\author{
Jacques BERLEUR \\ IFIP-TC9 Chair, IFIP-SIG9.2.2 Chair \\ University of Namur (Belgium) \\ jberleur@info.fundp.ac.be \\ and Jean-Marc GALAND \\ University of Liège, Belgium \\ jean-marc.galand@ckfin.minfin.be,jmgaland@ulg.ac.be
}

Keywords: Information Society, policy, eEurope, action plan, benchmark, European Commission, social issues, People first, IS for all, assessment

\section{TOWARDS AN INFORMATION SOCIETY?}

An official presentation of the European history "Towards an Information Society" can be found on the ISPO archives website (Information Society Project Office - 'Project' becoming 'Promoting' in 1998). ${ }^{1}$ It covers the period 1993-2000. This 'history' is just a sequence of documents, plans, events, and programmes, drawn from different initiatives within the European Commission, and which do not necessarily follow the same objectives and goals. The logic needs to be restored! The first part of this history has to be complemented by what is now under the responsibility of the European Commission General Directorate 'Information Society'.'

We can distinguish two periods in which we note a clear discontinuity, even in the names of the programmes, although no one would believe that the second is a complete re-build of the first! Two periods that may be associated with two names: the first with the former Commissioner Martin Bangemann $^{3}$ and the second with the former President of the Commission, Romano Prodi. ${ }^{4}$ When referring to 'policy', the official presentation opens 
with the second period, although some documents of the first are still mentioned. In other words, for people acquainted with the history, the ISPO site is today no longer considered as anything other than archives.

Is it a "European way for the Information Society"? That was, at least, the conviction of the Information Society Forum in its 1999 Report. ${ }^{5}$ We shall assess the answers.

\section{FIRST PERIOD: 1994-1999}

The first period of European policies is surely rooted in the decision of the European Council (Corfu, June 1994), which adopted the Bangemann report. But the main events and documents that accompany it are as famous too: the July 1994 Europe's way to the information society, An Action Plan. The report to the July 1996 Dublin Council meeting, Information Society: From Corfu to Dublin - The new emerging priorities that resulted, in November 1996, in a new Rolling Action Plan. ${ }^{6}$ Four other major initiatives shaped the landscape of the emerging European Information Society: the February 1995 Brussels G7 Conference on the Information Society, the Report Building the European Information Society for Us All, First Reflections of the High Level Group of Experts (HLEG) (Interim Report in January 1996, Final Report in April 1997), the 3 annual Reports (1996, 1997 and 1999) of the Information Society Forum, and also the Green Paper Living and Working in the Information Society: People First. Finally, other policies also emerged to support the development of the European Information Society, namely the Research Programmes of the Commission (Framework Programmes) where large funds were allocated to the field of information and communication technologies - it is still the case in the current (sixth) Programme.

\section{The Bangemann Report}

There is no doubt that the Report Europe and the Global Information Society, Recommendations to the European Council, known as the Bangemann Report (1994) is one of the major signposts in the landscape of the European Information Society. ${ }^{7}$ But we should remember that this report was already requested by a so called 'high-level group of experts' (it would be better to say a high-level of industrialists among whom the future President Romano Prodi) as a follow-up to the 1993 President Jacques Delors' White Paper on Growth, Competitiveness and Employment: The Challenges and Courses for Entering the XXIst century. ${ }^{8}$ 
This Report is also clearly an answer to the U.S.A. National Information Infrastructure: Agenda for Action of President Bill Clinton and VicePresident Al Gore whose announcement was made in September 1993. ${ }^{9}$

It is worth noting that where the USA speak of 'infrastructure', the Europeans seem to prefer a more global approach: A global Information Society. Six chapters: 1 . The information society - new ways of living and working together, 2. A market-driven revolution, 3. Completing the agenda, 4. The building blocks of the information society, 5. Financing the information society a task for the private sector, and 6. Follow-up. Some of the pervasive ideas that could not be missed: A challenge for the deciders. All together for employment! A social challenge: improve the quality of life, improve the efficiency of our social and economic organisation. Urgent? A market-driven revolution. New markets? But, more seriously, it is important to have a look at Section 22, 'Blazing the Trail - Ten Applications to Launch the Information Society.' Those applications and their objectives should be compared later to those of the eEurope initiative:

- Teleworking - More jobs, new jobs, for a mobile society;

- Distance Learning - Life-long learning for a changing society;

- A Network For Universities and Research Centres - Networking Europe's brain power;

- Telematic Services for SMEs - Re-launching a main engine for growth and employment in Europe;

- Road Traffic Management - Electronic roads for better quality of life;

- Air Traffic Control - An electronic airway for Europe;

- Healthcare Networks - Less costly and more effective healthcare systems for Europe's citizens;

- Electronic Tendering - More effective administration at lower cost;

- Trans-European Public Administration Network - Better government, cheaper government;

- City Information Highways - Bringing the information society into the home.

In an IFIP-WG9.2 Working Conference (Corfu, 1997), where we intended to discuss the 'Culture and Democracy revisited in the Global Information Society,' we had made a rough statistic of the interests of the Bangemann report and associated documents about such themes, in terms of wording. The result: Democracy is not mentioned; Culture is present 7 times, but about the cultural industries; language, linguistics are not worth noting, whilst 'market' is present 110 times. It has even a chapter about it: Chapter 2 is 'A market-driven revolution'! "

Later our Technology Assessment research team (CITA) went further in this first perception. We elucidated some indicators on the basis of the occurrence of associated keywords. For instance we derived the indicator 'Public sphere' from the occurrences of words such as public, 
administration, government, citizen, city, local, etc. The result is confirming our first perception, as stated in Table $1 .{ }^{11}$

\begin{tabular}{|l|c|}
\hline Indicators & Ranking \\
\hline Economic Values & 21.7 \\
\hline Information and Communication Technologies & 17.3 \\
\hline Information/Knowledge Society & 14.2 \\
\hline Public Sphere & 10.8 \\
\hline Actors & 10.7 \\
\hline Uses & 9.5 \\
\hline Methodology & 7.1 \\
\hline User's representation & 6.0 \\
\hline Social Values & 5.3 \\
\hline European Values & 2.5 \\
\hline
\end{tabular}

Table 1: Indicators in the Bangemann Report

Observing the ranking of these "European Values", we may have some doubts about a specific 'European way for the Information Society'!

\section{From an Action Plan to a Rolling Action Plan}

The 1994 Action plan covered 4 areas: the regulatory and legal framework (54 actions); the Networks, Basic Services, Applications and Content (27); the Social, Societal and Cultural Aspects (5); and some Promotion Activities (11). ${ }^{12}$

The main area was that of the regulatory and legal framework, but in domains where the economic aspects were prevalent: a competitive environment; standardisation, interconnection and interoperability; tariffs, intellectual property rights; electronic protection, legal protection and security; media ownership; privacy. Whereas the actions related to the social, societal and cultural aspects included orientations towards the flexible firm, proposals for the language industries, and agreements of regional cooperation for promoting a common information society approach, that is to say, with very loose link to real social, societal and cultural aspects.

The 1996 Rolling Action Plan tried to balance the trend, and to build the church in the middle of the village, or as underlined by many documents of the time "People at the Centre". "It covered four areas: Improving the Business Environment, Investing in the Future, People at the Centre, and 
Meeting the Global Challenge. Area 1 included, in July 1997, 45 actions; area 2,13; area 3,26, and area 4,16. The weight is still on the same side, but it seemed that some new balance was being sought. Unfortunately, it was purely a game of shifting some action from one category to another. Many of the actions of the area 'regulatory and legal framework' of the Action Plan had been shifted, in the Rolling Action Plan, to the area 'People at the Centre'. It would have been more honest to consider that they might have been better suited to the area 'Improving the Business Environment'!

\section{Other major initiatives}

\section{G7 Conference on the Information Society - Information Society and Development (ISAD) Conference}

Following the G7 Naples Summit in July 1994, Ministers from the G7 countries and Members of the European Commission met in Brussels on 25 and 26 February 1995 in the G7 Ministerial Conference on the Information Society. ${ }^{14}$ In their conclusions, eight core principles were endorsed for promoting new computer, telecommunications and media networks. The G7 identified 11 international pilot projects whose aim was to demonstrate the potential of the Information Society and stimulate its development. ${ }^{15}$

The Brussels conference emphasised the need for all countries, including developing nations, to be integrated. President of the Republic of South Africa, Nelson Mandela, and Executive Deputy President, Thabo Mbeki, convened the "Information Society and Development conference (ISAD)" in Midrand, South Africa, on 13-15 May 1996.

Sentences of the keynote address of Executive President Thabo Mbeki to the G-7 Conference remain in all our memories: "There are more telephone lines in Manhattan than in all of sub-Saharan Africa", and "half of humanity has never made a telephone call."

\section{Social Issues? The High Level of Experts and the Information Society Forum}

Mentioning the Bangemann report and the efforts directed by the technoeconomic paradigm without paying attention to other directions with more specific social accents cannot be a well-balanced presentation of the European way towards the Information Society. Among these other directions, we should mention first the so-called High Level Group of Experts (HLEG) established by Padraig Flynn, Commissioner for Employment and Social Affairs - i.e. another Directorate General (DG5) 
than the DG in charge of the 'Information Society' programme. We should also mention the Information Society Forum.

The Executive Summary of the HLEG "Interim Report" mentioned: "Social policy therefore merits equal if not more weight than economic policy in formulating our approach to the Information Society (IS). We believe that the Commission has paid insufficient attention to these issues so far, and in the following sections we elaborate these arguments in more detail." (...) "The Group welcomes the Commission's initiative to provide a major impulse into the broader policy debate surrounding the emerging IS, by setting up the HLEG. So far, the IS policy debate has been dominated by technological issues and, more recently, the appropriate regulatory economic environment, neglecting by and large some of the broader issues implicit in the 'society' notion."16

A set of 12 recommendations structures the final report, touching all the questions which are still prominent in the building up of the Information Society: education, regulation, efficiency of public services, development of flexible working arrangements, managing time, reprioritising 'full' employment, including everyone, European diversity, democracy.

Another initiative must be mentioned: the Information Society Forum. Its main purpose was to "provide the opportunity for representatives from a variety of different groups, including the social partners, to contribute to open debate and reflection on the challenges of the Information Society, including the social and societal aspects, as well as to raise the level of public awareness. The Forum will work on the framework for implementing the Information Society. The Forum should also indicate to the Commission the priority projects that need to be implemented...". ${ }^{17}$ The Information Society Forum has published 3 reports $(1996,1997,1999) .{ }^{18}$ The recommendations encompass Internet for all, economic, framework for the information society, global governance, consumers and citizen rights, cultural sustainability, the role of the public sector, environmental sustainability. "The ISF proposes that there is a distinctive European Way which has much to offer the world in meeting the challenges of the global information society. This is rooted in the search for dynamic equilibrium between different and sometimes competing concerns and goals. Its principles could be summarised as liberty, equality, fraternity, solidarity, and sustainability." (We underline)

The idea of a 'European way' may be found again in the last part of the Green Paper 'Living and Working in the Information Society: People First' (July 1996). ${ }^{19}$ "The Member States have developed social models with many common features including strong social rights and independent social partners, able to take responsibility for working conditions and for fair distribution." (...) "The European social model is built both on competition 
between enterprises and solidarity between citizens and Member States. The European Information Society must draw strongly from this economic, social and cultural strength, linking technological, economic and social aspects together in the creation of new opportunities for all its citizens."

\section{Supporting Research Programmes and Promotion Activities}

Information and Communication Technologies (ICT) have always received the lion's share of funding in the Research Programmes initiated by the European Commission, namely in the Framework Programmes (FP). Everybody calls to mind ESPRIT (European Strategic Programme for Research and Development in Information Technologies) or RACE (Research and Development in Advanced Communications Technologies for Europe). ICT Research Programmes counted for $42 \%$ of the budget in the 2nd FP (1987-91, 5,400 millions ECU), 39\% in the 3rd FP (1990-94, 5,700 millions ECU), 39\% in the 4th FP (1994-98, 12,300 millions ECU). The programme 'User friendly Information Society' (IST) has been funded up to 3,600 millions Euros during the 5th FP (1998-2002), out of a total budget of 13,700 millions Euros. It first covered 4 key actions: systems and services for the citizen, new methods of work and electronic commerce, multimedia content and tools, essential technologies and infrastructures. After this came research and technological development activities of a generic nature: future and emerging technologies; and finally the support for research infrastructures: research networking. Information Society Technologies (IST) priority of the 6thFP is funded at a level of 3,984 millions Euros out of a total of 17,883 millions Euros. But there are also other IST related activities that can be funded by other budgetary lines.

On the side of the supporting promotion activities, in November 1998, ISPO, the Information Society Project Office, became the Information Society Promotion Office.

Finally, among the promotion activities, let us mention that, on 30 March 1998, the multi-annual Community programme (1998-2002) to stimulate the establishment of the Information Society in Europe was adopted. The programme Promoting the Information Society (PROMISE) was launched. ${ }^{20}$ The programme aimed at: increasing public awareness and understanding of the potential impact of the Information Society; optimising the socio-economic benefits of the Information Society in Europe; and enhancing Europe's role and visibility within the global dimension of the Information Society. We shall see later that this programme is still waiting for a "successor" in the new European policies. 


\section{SECOND PERIOD: FROM 1999 AND BEYOND, eEurope}

\section{eEurope, An Information Society for All}

eEurope was initiated in 1999 by the new DG, Information Society, directed by the Finnish social-democrat commissioner Erkki Liikanen, under the then Commission presidency of Romano Prodi. Rather than a document derived from long-lasting stakeholders viewpoint confrontation, eEurope initiative presentation was written by three executives attached to the new DG. The arrival of a new commission team naturally raises the opportunity and the 'necessity' for the launching of such ambitious global policy documents, belonging to the category of visions more than to that of programmatic policies. ${ }^{21}$ eEurope is a remainder of the Bangemann Report and of all the other documents that preceded it. Furthermore, at a more basic level, those few years around the turn of the century were also years of significant Internet growth among the public at large. Thus, in order to avoid uncontrolled, anarchical or undesired development, public authorities felt it necessary to transform their vision of the Information Society, becoming increasingly conscious of the fact that, regardless of the importance you may give to the term, the Information Society was becoming reality and no longer just a dream for the future.

eEurope was adopted at the European Council of Lisbon in March 2000. The declared purpose was to take a unique opportunity to shape the Information Society, with respect to specific European values, principles and strengths. ${ }^{22}$ The overall and declared objectives of the eEurope initiative were:

- to bring every individual, household, school, enterprise and administration into the digital age, put prosaically, online;

- to create a digitally literate Europe sustained by an entrepreneurial culture ready to finance and develop new ideas;

- to ensure that the programme as a whole is socially inclusive, builds consumer trust and strengthens social cohesion. ${ }^{23}$

The initial eEurope document stated ten priorities for the implementation of this ambitious project that are worth being compared to the objectives of the ten applications of the Bangemann Report, which we mentioned earlier: bring European youth into the digital age; ensure cheaper Internet access; accelerate electronic commerce; provide researchers and students with high-speed Internet access; ensure secure electronic access through the use of smart cards; make risk capital readily available for hightech SMEs; increase the eParticipation of disabled people; maximise the use of digital technologies for healthcare; develop intelligent transport; and boost on-line government. 
The programme presented targets associated with deadlines ranging from March 2000 until the end of 2003. So, despite its characteristic of being a visionary plan more than a very pragmatic policy, eEurope endeavoured to define and consolidate a procedure of benchmarking.

\section{eEurope 2002, An Information Society for All, Action Plan}

As was the case for the Bangemann report, an Action Plan was produced immediately after the release of the original eEurope. The necessity for writing and adopting such a plan had been stressed during the first hasty evaluations, and officially requested by the Lisbon summit. Prepared in cooperation between the Council and the Commission and adopted during the European summit of Feira in June 2000, it was called An information society for all. The declared aim of this Action Plan was to define measures to achieve the goals that were set in Lisbon.

Some of the initial objectives present in the original eEurope document were modified, some withdrawn, and some added: the concept of 'working in the knowledge-based economy', as well as the idea of 'European digital content for global networks'. All objectives underwent a cosmetic change and were classified under more generic titles and presented in an " $e$ manner": eHealth, eLearning, eWorking, elnclusion, etc. All the major actors were identified for each action line and the final term was reduced to end 2002.

More importantly, eEurope 2002 was a more precise document than the initial version of eEurope. The sought-after logic was to evoke the policy as a dialogue between challenges posed and answers carried out. Three working methods were implemented to achieve the goals: the building of an appropriate legislative framework, the support to selected new services and infrastructures, a coordination and a comparative benchmarking of State performances (with a dedicated Council which should be held each spring).

eEurope 2002 reinforced the will present in eEurope of a strong benchmarking procedure. Commission and Council together defined a list of indicators. ${ }^{24}$ These were designed for both calibrating changes and measuring the impact of the application of eEurope.

\section{The Evaluation of the eEurope 2002 Initiative}

In December 2000, the European Council in Nice adopted an update of eEurope 2002. While noting the progresses made in different fields of the eEurope policy, the document formalised the concept of benchmarking and proposed structural indicators in order to make performance comparison possible between Member States, and to underline best practices. At the 
occasion of the Nice Council, it was asked that a first assessment of the impact and priorities of this programme should be presented at the spring 2001 Stockholm European Council.

During the Stockholm summit, the report eEurope 2002: Impacts and Priorities was presented. This summit also gave the opportunity to ask for eEurope to be raised to a higher priority level within the political agenda. But why this sudden preaching, since eEurope had already been ennobled one year before as the 'knowledge-based economy credo'? The truth is that at the March 2001 Council meeting in Stockholm, eEurope was already no longer "flavour of the month", according to Frank Mather, a member of the DG Information Society and one of the three authors of the eEurope document. ${ }^{25}$ In a few months, priorities had radically changed. Since the breakdown of the so-called new economy, the assertion was severely countered that it might one day provide a solution to almost every economic and social woe in Europe. Whereas this assertion had a central role in the eEurope reasoning, did this contribute to a renewed and more mature eEurope policy? We will analyse this question later. As one could have expected, the Stockholm evaluation gave a high satisfaction note to the completion of the first main tasks assigned to eEurope.

The next intermediary evaluation was undertaken in February $2002^{26}$ and the final evaluation of the eEurope 2002 process took place in February 2003 , while the new eEurope process (eEurope 2005) was launched in June 2002 in Sevilla.

Which are the most significant points in this evaluation? Among the 11 action areas and the 64 targets to be achieved before the end of 2002, the Commission points out a rapid growth of Internet connectivity, concerning "more than $90 \%$ of schools and businesses [...] and more than the half of Europeans". ${ }^{27}$ This fact would be linked to the decrease in access prices (considered as another satisfactory point), the establishment of the widest and fastest research backbone in the world (called GEANT) and the availability of basic eGovernment services in each Member State. Another satisfactory element, according to the Commission, lies in the implementation of a complete legislative regulatory framework for electronic communications and commerce - even if we personally would not give the main credit of this performance to eEurope. ${ }^{28}$ We shall return to this subject in the conclusion.

"The goal of a competitive knowledge-based economy is still some distance away, but eEurope has laid solid foundations." ${ }^{29}$ The main declared dissatisfaction in the assessment of the eEurope 2002 action plan comes from the remaining differences in connection rates between social groups (for instance, the gap between men and women remained proportionally constant) and Member States, from a stagnation of digital literacy among 
work forces or from a disappointing use rate of ICT and eBusiness by European SMEs.

\section{eEurope 2005 Action Plan - An Information Society for All}

The new action plan, adopted at the Sevilla Summit in June 2002, is focused on five main issues:

- Modern and on-line public services (eGovernment, eLearning, eHealth) to strengthen their productivity and accessibility;

- The promotion of a dynamic environment for eBusiness;

- A secured information infrastructure (eSecurity);

- Substantial availability of broadband access with competitive prices;

- Comparative benchmarking and the diffusion of best practices. ${ }^{30}$

This new action plan, covering the period 2003-2005, focuses on a more limited number of actions and targets. These remain clearly located in the Lisbon strategy of making Europe the most competitive and dynamic knowledge-based economy by 2010 . The credo is clear: there is a great but uncultivated potential lying in the Information Society, to improve competitiveness and quality of life. And broadband as well as multiplatform access is considered as the key factor to enlarge this potential. The task to be assigned to eEurope is to stimulate service and infrastructure creation and development, to create a favourable environment for private investment, capable of creating and sustaining a reciprocal positive feedback effect. $^{31}$

So, the purpose is to stimulate services (eGovernment, eLearning, eHealth, eBusiness) as well as the necessary infrastructure for them (available and affordable broadband access, security). Four intervention tools are privileged to achieve this general goal: general policy measures of legislative nature, measures aimed at facilitating good practices exchanges, comparative benchmarking and an overall coordination of existing policies (led by a steering group).

As far as services are concerned, the accent given is on the production of (relevant) content in order to get people interested. In this regard, eEurope 2005 is going to pursue the eContent programme initiated with eEurope 2002. Its purpose is to support "the increased availability, use and distribution of European digital content" and to improve "access for all to high-quality digital content on the global networks, in a multiplicity of languages", including - and above all - governmental content, but excluding massive digitisation of already existing content. ${ }^{32}$ The budget to be requested for years 2003 and 2004 from the European Parliament is envisaged as 51.5 million Euros. 
What about social inclusion issues? Whereas eEurope 2002 underscored the problem of extending Internet connectivity across Europe, this connectivity seems to be considered as granted, in the reasoning of eEurope 2005. In the Action Lines, very little is currently said about support or measures favouring social inclusion! Even the fundamental concern of digital literacy is hardly mentioned, no more than either Public Internet Access Points (PIAPs) or public websites accessibility. So, although Erkki Liikanen stated as a principle petition that every eEurope 2005 action had to be "integrative in order to be efficient" and that "every citizen no matter his personal or geographical situation should benefit from opportunities offered by the knowledge-based society", our concern is that there is a clear mismatch between declared goals and chosen action tools. ${ }^{33}$ The Information Society for All concept is viewed almost entirely through support to broadband and multi-platform access - the latter justified by the assertion that not everyone will be able to buy and use a PC, though eEurope 2005 mid-term revision, which occurred in 2004, seems to pay more attention to this inclusion aspect, according to the conclusions of various ad hoc consultations.

The evaluation paper of the eEurope 2002 initiative itself declared that "increasing effective use of the Internet is the focus of the next step, eEurope 2005": more eCommerce, more effective use in the classroom, more use by governments, etc. ${ }^{34}$ This argumentation about effective use is quite curious and disturbing. ${ }^{35}$ Can we imagine countries pushing the equipment of households in television sets and then asking people to really use them? We must realise, that since eEurope deliberately chose to be a market-push initiative, this reasoning is anything but logical: if you want the industry to develop and promote new uses, whatever the final goal may be (employment, competitiveness, social inclusion, or all three), you merely have to pay to help the content pipes fill up.

This is currently an axial argumentation in eEurope 2005: a more effective use of computers requires the improvement of education and skills in order to improve productivity and competitiveness in the EU economy as a whole. The ultimate goal of the eEurope policy clearly remains mostly mechanical and economic, but in no way directly political: it is to improve the competitiveness of Europe. ${ }^{36}$

\section{eEurope 2005 Updates}

As we have elucidated here, there was a lack, in terms of cohesion, of an integrated IS European policy, as well as in terms of financial pan-European support for the eEurope Action Plan. A 2003-2005 programme called 
MODINIS has been launched, which is intended to provide "financial support for the implementation of the eEurope 2005 Action Plan." "37

The MODINIS program also appears as an attempt to complete the benchmarking procedure with more qualitative indicators; such an observation was also made by the Commission (and endorsed by the Council in February 2004), in recognition of a relative weakness in the benchmarking procedure in the eEurope mid-term evaluation, at least with regard to a weak linkage between indicators and the objective completion evidence of the eEurope 2005 measures.

However, we regret the absence of a general questioning of the initial eEurope 2005 objectives. Open consultations that were undertaken should have observed the lack of such a will. Thus the 'Update' of the Action Plan is officially limited to a 'Readjustment'. Yet writing the contrary would have sounded like a disavowal. It is also true that this Update remains an update, being only "a series of preparatory steps towards the establishment of a new policy framework for ICT policy in Europe. 38

The Update contains a formal switch in the rhetoric: it proposes the adoption of a demand-based approach, in addition to stating the will to measure the impact of the Information Society in terms of efficiency gains as well as of quality of work ... and life (including citizenship and governance aspects).

Let us hope that their concept of demand and eInclusion will not remain too instrumental in the future. For instance, there is talk in the mid-term evaluation of sustaining demand shortages in rural and isolated regions by measures appealing to EU structural funds, in a curiously Keynesian-like approach... Even if we agree that taking inclusion for a goal in itself makes no sense we may still wonder whether the Lisbon strategy is the most comprehensive, socially-oriented approach to dealing with such inclusion and demand...

The new policy fragments finally seem to reinforce the role and the presence of multi-level stakeholders in the definition of policies, in a socalled tradition within our European way to the Information society... The eEurope Advisory Group should work as such a gathering place, as well as the MODINIS programme, which should concentrate on spreading good practices and building stakeholders networks.

\section{Overall Appreciation of the eEurope Assessment Process}

Concerning the evaluation of eEurope 2005, we note that the European Telecom Council of December 2002 has adopted the renewed methodology and the list of benchmarking indicators proposed by the Commission. Compared to the eEurope 2002 indicators, the new ones seem to be more 
precise. ${ }^{39}$ They also include direct comparison with countries outside the EU. As in the past, benchmarking and yearly assessments are intended to take place each spring.

As a general consideration, a significant flat note to this evaluation process comes from the fact that these indicators cannot properly be linked to eEurope actions. ${ }^{40}$ They are general indicators, insufficiently welldesigned to provide a satisfactory benchmarking of directed policies: the proper influence of measures deriving from the eEurope action plan can in no way be isolated from other major factors, such as economic issues of purchasing power or inflation. For instance, it seems difficult to link in any real way the percentage of individuals regularly using the Internet with any single item of the eEurope action plan. Using such generic, one-dimensional tools may lead to over-subjective interpretation.

Furthermore, the fact that the main controller is the controlled person itself (the Commission), rather than research institutes or independent public bodies, raises questions. The Council should engage in promoting and committing rigorous control, such as could be achieved by delegating the control power - including the definition of the benchmarking indicators - to an independent committee. A strengthened eEurope steering group - the group to which eEurope has given the charge of coordinating existing policies about Information Society - could be the basic core from which to derive a specific assessment organisation. This steering group is a concrete application of what political scientists have called 'new governance': it involves representatives from official instances and from so-called interested groups, or 'civil society' - even if it has no deep democratic legitimacy. This should be scrutinised carefully.

A very good score should nevertheless be given to the eEurope evaluation process, since exchange of good practices and comparative benchmarking are simply added to the action tools of eEurope among two far more classical tools (policy measures and overall coordination of existing policies). According to the action lines, selected good practices would be enhanced to broaden their applicability, transformed into guidelines, analysed and disseminated. ${ }^{41}$ Well-functioning benchmarking would ease the making of this selection.

\section{Information Society: How to Achieve a Well-Balanced Diffusion Across all Member States and Candidate Countries?}

No specific action has been carried out by the successive versions of the eEurope action plans to ensure their harmonious development and expansion among the different Member States. Indeed, we have to acknowledge the existence of a centre and of a periphery concerning the 
extent of the deployment of the Information Society. Greece, and to a lesser extent Spain, Portugal, Italy and France, are far from presenting the same figures as the Netherlands, Sweden, Denmark, or Ireland. ${ }^{42}$

At least this problem is mentioned in the eEurope 2005 Action Plan: the Member States should support broadband deployment in less favoured areas. We will add no comment to this, except that broadband is really considered in eEurope 2005 as a universal panacea.

The European Regional Development Fund (ERDF) has developed a policy for boosting regional competitiveness - besides the structural funds that might be awarded to some eProjects. For the period 2000-2006, the ERDF decided to support measures relating to one or more of three specific domains: knowledge-based regional economies and technological innovation; eEuropeRegio: the information society and regional development; regional identity and sustainable development. ${ }^{43}$ Some 400 million Euros are planned to be budgeted until 2006, mainly in co-financing regional projects and in respect of the subsidiarity principle. The emphasis, according to Commissioner Barnier, is clearly set on competitiveness and sustainable development. Peripheral regions - both geographically and in terms of their position on an eDevelopment level - should feel concerned. ${ }^{44}$

As regards new Member States to be integrated in 2004, an important measure was announced in Stockholm in June 2001: the launching of the eEurope +2003 Action Plan. ${ }^{45}$ It claimed to "mirror the priority objectives and targets of eEurope", but to "provide for actions which tackle the specific situation of the Candidate Countries". It seems evident that there is an important emphasis on liberalisation and implementation of the already acquired EU legislative framework. The accent is on the initial eEurope priorities: cheaper - some price regulation would be allowed - and faster Internet access, skills development and use stimulation. Since the funding that these countries could provide to such policies is not necessarily high, they are encouraged to seek funds in the PHARE programme and support from the international financial institutions. A progress report has been made public in June 2002 and it brought to light crucial disparities between joining Member States (and candidate countries such as Bulgaria, Romania and Turkey) in terms of inclusion in an Information Society - or whatever we want to call it. A fundamental problem is the cost of telephone calls and the reliability of traditional analogical connections, added to the fact that no other massive connectivity infrastructure has yet been developed or even planned. Among others, Lithuania, Latvia, Slovakia and Hungary also present dramatic figures on access costs as well as on digital literacy or computer penetration in schools. One may pretend that there are more important and urgent matters than this. But without taking a position on this 
assertion, this situation is nonetheless symbolic of the challenges that the enlargement process will have to cope with. ${ }^{46}$

The EU policy towards peripheral States may be considered as a subsidiarity action and as a legitimate worry about foresight and cohesion since important gaps - in various policy areas - may hinder the continuation of the enlargement process. But, while enthusiastic literature has given credit to the idea that the arrival of the Information Society should solve regional disparities, some rudimentary or elementary political economy principles and market realities demonstrate this is far from being the case: oligopoly structures, cultural, legal or economic barriers, play a negative role. Paschal Preston pleaded for less "economism" in EU strategy. Have such voices been heard? $?^{47}$

\section{The Information Society: Policy Elements Besides eEurope}

To whom are documents of so-called policies such as eEurope addressed? They challenge Member States to make ambitious commitments. They address invitations to the private sector to collaborate with the Commission and the Member States to share the same objectives. They indicate the initiatives the Commission will take or is willing to take. And, finally, they describe a kind of idealistic coordinated approach to European policies on the so-called Information Society. ${ }^{48}$

But no specific fund is directly allocated to eEurope! The vocation of successive eEurope plans has voluntarily remained general policy documents aimed at underlining certain European priorities. But they have to be put in concrete form by specific research programmes, initiated by a European DG other than the Information Society DG, the Member States or other decision levels, so that European-wide actions may derive from existing programmes or programmes to come.

Concerning eEurope 2005, new programmes will be proposed and fundraised by the Commission. The Action Plan also counts on programmes that are likely to be continued and that the Commission will sustain for that purpose. This, for instance, is the case of eContent. ${ }^{49}$ The eTEN programme initiated in 1997 is also mainly aimed at helping launch and develop eServices - mainly public services - for trans-European goals and on a socially inclusive basis. ${ }^{50}$ This programme is derived from the TransEuropean Network policy. The IDA programme, devoted to interoperability between different administrations, is another major programme which has been launched and which will continue to be used to put eEurope into concrete actions. The eEurope 2005 Action Plan also expects to keep the heritage of the 1998-2002 PROMISE programme which aimed, as we mentioned in the analysis of the first period, at promoting and stimulating 
the Information Society and its most promising applications among the public at large, at analysing relationships between all the Information Society tenants (societal, economic, legal), and at working on collaborations between different levels of governments and private partners.

The new (sixth) Framework Programme of the European Union (FP6) presents an ambitious Information Society Technologies (IST) priority and programme, which will be endowed with no less than 3,984 million Euros. This thematic priority will in a large part be dedicated to the implementation of European Information Society policies. Its ambition is even to go far beyond the eEurope 2005 priorities. This kind of programme is helpful to gain the lasting support of industrial sectors as it favours major partnerships included in broad and firm concepts and tools like integrated projects and so-called networks of excellence. The global objective of the IST thematic priority of the FP6 seems even more comprehensive and ambitious from the societal point of view than the eEurope Action Plan itself. Reality will show us how these good intentions translate into projects and practices, but the goal of strengthening social cohesion appears at the same level as growth and lasting competitiveness and not as an estimated and hoped for consequence of the invisible hand as it is the case in eEurope. ${ }^{51}$

And, importantly, besides these trans-European programmes, eEurope 2005 has to rely on its persuasive power and on a large-scale adoption of its beliefs and objectives to become reality. Most Member States have already adopted national plans that are more or less based on eEurope ideology, and this is also the case for all 10 new Member States.

Besides all these elements linked to eEurope, the Information Society landscape in Europe is shaped by a consequential legislative framework which has - or is going to have - a deep impact on European, national and sub-national policies and actions. ${ }^{52}$ The purpose for developing an appropriate legislative framework is to ensure harmonious development and the expansion of policies - such as eEurope - throughout all Member States. In that respect, we have to acknowledge a particular efficiency of the European Union. It has succeeded in developing a complete regulatory framework that is far more integrative than the American one. ${ }^{53}$ The latter as with almost every American legislation, because they are by nature reactive - was underpinned by a confrontational logic and has therefore encountered far more resistance. So far, the European approach has demonstrated better and more long-lasting results than the American one in issues such as telecom liberalisation, privacy or intellectual property, although the European approach may be felt as formal. This is probably partly due to the nature of European legislation, which is more accompanying than binding or forbidding. ${ }^{54}$ But this does not mean that critical voices are not heard, to which we shall return later. Let us note that 
the tragic 9/11 tragic terrorist attacks on the USA have led to still more nonconstructive legal developments - such as, for instance, those included in the "Patriot Act".

\section{A TENTATIVE ASSESSMENT: WHICH POLICIES AND FOR WHAT?}

\section{General Philosophy}

As it emerges from our analyses, the Information Society has been conceived from the start with very little concern for cultural, social, and even governmental, political, and societal aspects. It has been mostly a market-push initiative or, as we have observed, mostly technological, mechanical, and economic. A group of CEOs of computer firms in the USA declared just before the 1995 Brussels meeting: "Let's put the private sector in the driver's seat." 55

There is also a belief that the 'digital age' or the 'Information Society' is inevitable, inescapable: we have to lead people into it, and it is their interest for the future. The eManner is the law: eEducation, eLearning, eHealth, eWorking, eGovernance,... are the buzzwords which dominate current rhetoric!

At the same time, we have noted the weakness of social indicators in the benchmarking. Everything is thought of in terms of markets, and expansion of the economic model, even given the lukewarm economic improvement we have mentioned.

We could say the same of the regulatory framework. ${ }^{56}$ Let us briefly evoke the logic of development of the European Regulatory Framework. It is said to build confidence, but in what and in favour of whom? The first legal intervention was to protect intellectual property and related rights, or as said by the Bangemann report itself, it was about protecting the agreed investments by those who tomorrow will become the providers of services and information. Protecting investors guarantees the presence of content on the Internet. The transactions still have to be developed, between professionals ( $\mathrm{B}$ to $\mathrm{B}$ ) or with consumers ( $\mathrm{B}$ to $\mathrm{C}$ ). To do this, the issue is one of reassuring partners about the identity of their opposites in a transaction, about the authentication of messages and the assurance of confidentiality. The legislation, as on the subject of electronic signatures, granting them the same value as written signatures and granting electronic documents the same value as written ones, answers this concern. Next step: the protection of investments and transactions, this equally demands the possibility of detecting illicit schemes on the Internet and of efficiently 
punishing their perpetrators. The Convention on Cybercrime adopted by the Members of the Council of Europe, as well as by Australia, Canada and the USA makes the Internet more reliable and confident! ${ }^{57}$

The biggest differences between Europe and the USA could be on the questions of freedom of expression and on privacy protection.

\section{First Reflections on the First Period: A Market Europe}

The first five years of the so-called Information Society Programme have been decisive in shaping our European Society of today. Alvaro de Miranda and Morten Kristiansen analyse them in terms of tension between 'Social Europe' and 'Market Europe'. ${ }^{58}$ We share their analysis not only for the first period, but also for what we have called the second one. The Bangemann report, from a pure lexicographic point of view, is an argument, as we have shown earlier. The analysis of eEurope programmes reinforces the result. But more than words are at issue. Europe has chosen to speak of 'the global information society' whereas others (USA and G7) were mentioning 'national or global information infrastructure'. The pace to 'Society' indicates a kind of technological, mechanical, and economic determinism that everybody has to face. If not, we are at risk, even promised, to a quick societal decline. The Bangemann report title itself makes explicit the link between the concept of 'Information Society' and 'global' (in French 'planétaire'). ${ }^{59}$

As soon as the concept of information society is accredited, the next message, on the role of the private sector, affects the role of the social, societal, and public authorities. A. de Miranda et al. insist on the decisive character of the 1993 White Paper of Jacques Delors on growth, competitiveness, and employment, which in their view is the most influent paper on the Information Society, a paper which is the source of "all the documents to come". ${ }^{60}$ This White Paper faces the dramatic rate of unemployment in Europe, but answers that unemployment is essentially due to social policies (regulation and protection of the labour market, welfare policies,...) that reduce European competitiveness. Therefore, liberalisation has become the major keyword.

Social policies will no longer be at the forefront of Information Society policies, and reports such as of the High Level Group of Experts (HLEG) or of the Information Society Forum (ISF) are initiatives "from outside" or "snatched" as the opportunity presented. Curiously, the HLEG and the ISF have disappeared from the scene of the new eEurope. As stressed by Bernard Cassen, eEurope was destined to mean 'Europe, Inc.': he was commenting a paper of the Financial Times $A$ corporate Plan for Europe, Inc. ${ }^{61}$ Although the HLEG and the ISF have insisted on the choices to be 
made, it seems that the Commission is now just offering 'to adapt ourselves' to that situation.

In official documents the words People First, or People centred are a tissue of misleading metaphors, which hide underlying interests behind particular policies. It is ideology that now justifies policies. The traditional Social Europe has largely opened the doors to the Market Europe, without keeping the usual balance between both. The current debate on the European constitutional treaty reinforces our perception.

\section{About the Legitimacy of $e$ Europe}

Europe is now equipped with a general Information Society policy mainly through the succession of the eEurope Action Plans. We have to wonder where the legitimacy of such a policy lies, a policy that claims to cause a profound change in the life of all the European citizens.

Why does Europe's Information Society policy remind us of modern States from the 1930's with their Keynesian entrepreneurial attitudes? Have the markets failed to provide an autonomous and self-regulated solution to these concerns of societal adoption of ICTs (partly due to problems of scale)? And must the EU then be forced to act as the most appropriate political level to make things change? Has Europe become, like others, a political system where intervention in technological development is considered unnatural, because each political trend tries to position itself as an outside bidder to the others on such subjects? Is Europe a system captured by power groups or class interests? $?^{62}$

The EU policy is a logical consequence and continuity of traditional European research, competition and industrial policy initiatives. We consider that it is also an heir of what has become a real European way of doing politics: strong law building, prospective policy with hard agenda setting and calendars, binding political commitment.

Is there any democratic control? No more than in other aspects of European policies. In the first months of eEurope, the DG "InfSo" let visitors to its website review eEurope and give their comments. Unfortunately, it was a clumsy attempt to involve citizens - or at best users or concerned people. Beyond the fact that this looked more like a way to give oneself a good conscience than a democratic measure, no procedure had really been foreseen to evaluate and use this feedback. Few reports start to be published for assessing, for instance, the impact of eEurope strategy on growth and employment. ${ }^{63}$

Thus legitimacy cannot lie in the assessment procedures that have been implemented, since these are not known or public. While assessment is not an ancient tradition in the European Commission - there has for instance 
been no official assessment of the Bangemann report - methods and indicators have in all seriousness been built in order to evaluate the effects of eEurope action plans. Furthermore, there is a clear formal continuity between the two plans in terms of concepts and benchmarking methods employed, of seemingly continuous guidelines. Nevertheless, not enough lessons are taken from all the benchmarking and assessments, as if most of the commitments taken in eEurope 2002 were considered as definitely in place at the moment of writing eEurope 2005.

One may also have one's own appreciation of the benchmarking indicators. Do they go further than an evaluation of the penetration rate of Information Society policy? Adoption, penetration, connection are not primary concepts for appropriation! Moreover, it seems as if every new policy statement gives rise to a switch to a next and subsequent point in a reasoning that should have been decided from the start and which should mechanically be followed. So, even if one accepts the assertion developed in Lisbon that we are on "the way to the most competitive knowledge-based economy", is it a reason not to question the methods that are chosen and the resulting societal evolution? Should we not also question the timing, as well as the effect these policies have on ICT take-up? As Ducatel, Webster and Herrmann stated already three years ago, "if we want the 'society' in Information Society to be more than a rhetorical device, [it is necessary] to develop a more sophisticated appreciation of these social issues". And thus we must accept lessons and failures from the past, instead of repeating over and over that this time, conditions are really different. ${ }^{64}$ This means than the social and societal aspects should be reflected in the indicators.

As stressed before, the first period of the Bangemann report was already 'Market Europe oriented', but the HLEG and ISF reports, for instance, still manifested a preoccupation with social values, social challenges, social policies, etc. In short, the insistence on People First, People Centred policies, showed, at least in words, the conviction that a European Social Model of the Information Society was possible, that the emphasis could be put on Society rather than on Information. But was social cohesion never a genuine concern? Today, even the so-called 'socially inclusive issues' seem to have disappeared from the action lines of eEurope 2005.

One might argue that legitimacy comes from the kind of a 'natural balance' included in EU policies: although the Commission (the European bureaucracy) is quite monolithic and may seem to function as an autonomous power, there is plenty of national and external influence in its decisions. Furthermore, the Commission is far from being the single centre of political forces in European decisions. Every EU presidency (rolling every 6 months to another Member State) wants to leave its own mark in 
each policy domain, though this does not necessarily work in favour of the coherence and permanence of such a policy.

Anyway, it is true that a large number of interests are represented in the decision process and, moreover, that a certain common ground of European political culture exists, which works in favour of non-openly competitive decisional processes. The latter is usually based on achieving satisfactory compromise even before the political issue treated gets formally discussed. While one could argue that this way of acting rather diminishes both the transparency of the process and the inclusion of interest groups, we nonetheless observe that in the eEurope initiative - originally prepared by three experts - the Commission's impulsion has never been seriously disputed or challenged.

One lesson from such an evaluation of EC-policy as ours is that academic people and EC decision-makers seem to live in two separate worlds. ${ }^{65}$ While the former "have repeatedly observed that discourses about ICT are driven by technological determinism", the latter do not seem to bother about such ivory tower appreciation, or to question their beliefs in this, or in other external regards. Maybe a disenchanted vision of things does not suit the political discourse, aimed as it is at pushing forward 'positive' visions. ${ }^{66}$ Another way of seeing things is that we enter the Internet galaxy at full speed, but fully confused, as Manuel Castells describes: evolution has been so fast that research has struggled to keep up and been unable to produce enough empirical on about the how, the what and the why, leaving empty spaces for futile discourse. ${ }^{67}$ This way of thinking cannot satisfy scientific requirements, neither does it accord with the democratic principles which characterise Social Europe, as long, that is, as it is not pervaded by the laissez-faire of Market Europe.

\section{About European Policies at Large}

On a wider basis, all this raises questions on the nature of mostly proactive European policies, which do not benefit from strong popular adherence. With Dominique Wolton, we would like to highlight the paradox between, on the one side, all these policies that work for more and more communication between peoples and between groups and, on the other, the fact that the ongoing trend of more communication and information in no way eases the rise of a unified European conscience. ${ }^{68}$ Policy makers and citizens do not share the necessary minimal common representations for a dialogue to be initiated and built. And this is even truer when information and communication are co-substantial to discourses on Europe. Indeed, as Wolton points out, from a certain point of view, information and communication are Europe. Yet the more it seems technically easy to build 
a communication-Europe, the more the difficulty appears on the actual content level of this Europe. ${ }^{69}$ The effort the European Union has to make on its communication should, according to Wolton, polarise in two dimensions: a more explicit - and transparent - communication on the forces and weaknesses of Europe and European policies; a less institutional, formal, promotional communication than demonstrated by previous models of the last thirty-five years. If identity may have been, for past decades and centuries, a precondition of communication, communication must nowadays help to strengthen identity. ${ }^{70}$ From a more prosaic standpoint, does the eEurope jargon and its 'Information Society' sound good - or even sound at all - to the lambda citizen?

\section{On the Nature of the eEurope Initiative}

1999 and eEurope has meant a gearshift to a greater density and political consistence of the European discourse on Information Society. While the market aspect of eEurope is seemingly less pregnant than in its predecessors, we cannot avoid thinking that social and societal considerations have been sprinkled on what mainly remains a market-driven plan. In our opinion, the market-driven option has never been questioned since it was chosen as a central pivot in the Delors White Paper. Indeed, some statements clearly show an in-depth, long-lasting inclination of policies that will remain difficult to change. As a piece of evidence, we notice that the matter of efficient uses comes in every official reasoning, far after questions concerning the 'critical mass' of users and the availability of broadband pipes. ${ }^{71}$ It seems as though mass ICT adoption is the only way to be considered for the only problem that would really be handled: escaping from the 'classic chicken-and-egg scenario' and entering the Internet economy. ${ }^{72}$

The latest elements of European policy on Information society maintain the same convergent discourse. eEurope shares with its predecessors which were in a certain measure, as shown, linked to US discourses - a common cognitive map. ${ }^{73}$ Do we remain in the same main trend that characterised the 90 's, the building of large-scale infra-structural projects at the inter-sectoral level, which followed another trend consisting of political intervention in meso-industrial development? ${ }^{74}$ Anyway, beyond the fulfilment of the Lisbon strategy, our point is that eEurope has failed to formulate a clear political and citizen-oriented strategy. We see eEurope heading for something, but what precisely? Some even claim that eEurope would be a 'Commission's brand' rather than a strategy...

Despite regretting some significant elements, this policy is above all a discourse that has to exist in order to pose a welcome European vision and 
challenge. Few would want it to remain merely 'flavour of the month'. This is even more true, now that we must acknowledge a heavy trend to immaterialisation of everyday activities, backed by an accumulation of knowledge, an increase of electronic devices, interconnectivity and accelerating diffusion of digital technical applications across an increasing panel of sectors. ${ }^{76}$ So there is indeed a crucial role for technical progress which we certainly do not restrict to so-called technological determinism! And thus there is an even more crucial need for (adequate) policies on these concerns.

To recapitulate, the nature of eEurope action currently remains modelled by the obstinate classicism of a vision generated within inner administrative circles and seeking legitimacy through reliance on chosen expert groups, a vision translated into vague action plans and embellished with some social or democratic concerns. And despite a will to make things change on a wider level, despite ambitious and various action plans, the range of ground-level action remains tight and often limited to small-scale demonstrators. ${ }^{77}$ The relevance of this policy will be shown at the local level, while on the other side it will have also to work for harmonious global development. Regarding this, it may be less appropriate to set up a number of new international instances, than to buttress those already existing with clear, sustainable rules and guidelines.

1 History, Towards the Information Society, http://europa.eu.int/ISPO/basics/i_history.html, updated on 02/03/01.

The Information Society Homepage, http://europa.eu.int/information_society/

3 Commissioner from 1989 to 1999.

4 President from 1999 to 2004.

5 Information Society Forum, A European way for the Information Society, 3rd annual report, 1999, http://europa.eu.int/ISPO/policy/isf/i_documents.html Communication from the Commission to the Council, the European Parliament, the Economic and Social Committee and the Committee of the Regions - The Information Society: From Corfu to Dublin "The new emerging priorities"; COM(96)395 final of 24 July 1996. Europe at the Forefront of the Global Information Society: Rolling Action Plan"; COM(96)607final; 27 November 1996, http://europa.eu.int/ISPO/policy/i_rollingaction.html

Europe and the Global Information Society, Recommendations to the European

Council, Corfu (Greece), June 1994, http://europa.eu.int/ISPO/docs/basics/docs/bangemann.pdf 
8

White Paper. on growth, competitiveness, and employment: The challenges and ways forward into the 21 st century COM(93) 700 final. Brussels, 5 December 1993.

9 The National Information Infrastructure: Agenda for Action, http://www.ibiblio.org/nii/NII-Table-of-Contents.html

10

Jacques Berleur and Diane Whitehouse, Eds., An Ethical Global Information Society: Culture and Democracy Revisited, Chapman \& Hall, 1997 (now available at Kluwer Academic Publ., Boston), p. 8.

11 Béatrice Van Bastelaer, eEurope ou les cohérences et incohérences de la Société européenne de l'Information, Working Paper of the COST 269 Group "User Aspects of ICTs ". See:

http://www.info.fundp.ac.be/ cita/publications/e_Europe.pdf

12 Requested by the European Council during its Corfu meeting and approved in the Essen Council (December 1994) : Europe's Way to the Information Society - An Action Plan, COM(94)347 final, Brussels 19 July 1994, http:/www.europa.eu.int/ISPO/docs/htmlgenerated/i_COM(94)347final.html

A Rolling Action Plan, COM(96)607, Brussels 31 July 1997 (version 1.3; version 1 in 1996), http://europa.eu.int/ISPO/policy/i_rollingaction.html G-7 Information Society Conference, http://www.europa.eu.int/ISPO/intcoop/g8/i_g8conference.html

15 The pilot projects were : Global Inventory Project, Global Interoperability for Broadband Networks, Transcultural Education and Training for Language Learning, Electronic Libraries, Multimedia Access To World Cultural Heritage, Environment and Natural Resources Management, Global Emergency Management Information Network Initiative, Global Healthcare Applications, Government On-line, Global Marketplace for Small and Medium Enterprises, and Maritime Information Society.

Building the European Information Society for Us All. First Reflections of the High Level Group of Experts (HLEG), Interim Report, January, 1996. Final Report, April 1997 http://europa.eu.int/ISPO/docs/topics/docs/hlge_final_en_97.rtf Mission and Role of the Information Society Forum, http://www.europa.eu.int/ISPO/policy/isf/i_mission.html Information Society Forum documents, http://www.europa.eu.int/ISPO/policy/isf/i documents.html Green Paper - Living and Working in the Information Society: People First; COM(96)389, July 1996, http://europa.eu.int/comm/off/green/index_en.htm\#1996 Council Decision 98/253/EC of 30 March 1998; Official Journal, L107 of 07 April 1998.

21 eEurope Initiative: http://europa.eu.int/ISPO/basics/i_europe.html 
22. eEurope. An information Society For All. Communication on a Commission Initiative for the Special European Council of Lisbon, 23 and 24 March 2000. http://europa.eu.int/information_society/eeurope/news_library/pdf_files/initiati ve_en.pdf

eEurope, an Information Society for All, Initial document on the web site of the Commission, http:/www.europa.eu.int/information_society/eeurope/2002/news_library/docu ments/text_en.htm

Benchmarking eEurope :

http://europa.eu.int/information_society/eeurope/2002/benchmarking/index_en. htm Interviewed by Béatrice van Bastelaer.

Communication from the Commission to the Council, the European Parliament, the Economic and Social Committee and the Committee of the Regions, eEurope Benchmarking, Report $\operatorname{COM(2002)~62,~http://europa.eu.int/eur-~}$ lex/en/com/cnc/en_cnc_month_2002_02.html Commission of the European Communities, eEurope 2002, Final Report, Communication from the Commission to the Council, the European Parliament, the Economic and Social Committee and the Committee of the Regions, February 2003, http://europa.eu.int/information_society/eeurope/news_library/documents/acte_ eEurope_2002_en.doc

New Regulatory Framework for electronic communications infrastructure and associated services, http://europa.eu.int/information_society/topics/telecoms/regulatory/new_rf/text _en.htm and eCommunications Networks and Services, EU Policy and Regulation, http://europa.eu.int/information_society/topics/ecomm/text_en.htm Commission of the European Communities, eEurope 2002 Final Report, doc. cit.

Commission of the European Communities, eEurope 2005: An information society for all, Action Plan to be presented in view of the Sevilla European Council (June 2002), Com(2002) 263 final, May 2002, http://europa.eu.int/prelex/detail_dossier_real.cfm?CL=fr\&DosId=173882 Ibid.

32 Commission of the European Communities, DG Information Society, eContent. A multiannual Community programme to stimulate the development and use of European digital content on the global networks and to promote the linguistic diversity in the Information Society. Work Programme 2003-2004, 2002, $\mathrm{ftp}: / / \mathrm{ftp} . c 0$ rdis.lu/pub/econtent/docs/work_programme_2003_2004_en.pdf Liikanen Erkki, "Priorités pour l'eEurope", in Le Soir, Brussels, 15 mars 2002. Ibid. 
For instance, "schools not only connected but also making full use of the Internet in class" (ibid.).

Ibid.

The MODINIS Programme,

http://europa.eu.int/information_society/eeurope/2005/all_about/modinis/text_e n.htm

eEurope 2005 Action Plan : an Update.

Commission of the European Communities, eEurope 2005: Benchmarking indicators, Communication from the Commission to the Council and the European Parliament, $\operatorname{COM}(2002) 655$ final, November 2002, http://europa.eu.int/eur-lex/en/com/cnc/2002/com2002_0655en01.pdf

Besides the difficulty, here maybe more than in other policy domains, of having recent data at disposal as well as sufficiently defined statistics between Member States to ensure the homogeneity of the indicators.

41 Commission of the European Communities, eEurope 2005, doc. cit.

42 Gallup Europe, Flash Eurobarometer 125: Internet and the Public at Large, May-June 2002, and Commission of the European Communities, eEurope 2002 Final Report, Communication from the Commission to the Council, the European Parliament, the Economic and Social Committee and the Committee of the Regions, February 2003, $\operatorname{COM(2003)~} 66$ final, http://europa.eu.int/prelex/detail_dossier_real.cfm?CL=en\&DosId $=180710$ INFOREGIO, The regions and the new economy - Guidelines for innovative actions co-funded by the European Regional Development Fund 2000-06, http://europa.eu.int/comm/regional_policy/innovation/pdf/sheet/inforegio_en.p df

Inforegio Panorama, Politique de Cohésion: quel avenir dans une Union élargie?, Nr.3, Communautés Européennes, 2001.

The Candidate Countries with the assistance of the European Commission, eEurope +2003 . A cooperative effort to implement the Information Society in Europe. Action Plan, June 2001, http://europa.eu.int/information_society/topics/international/regulatory/eeurope plus/doc/eEurope_june2001.pdf Please also note that eEurope 2005 plans to integrate smoothly, step by step, new Member States into its policy and benchmarking.

Central and Eastern Europe Information Society Benchmarks, Summary Report, September 2004 http://europa.eu.int/information_society/eeurope/2005/all_about/benchmarking/ index_en.htm

Preston Paschal, "The Information Superhighway and the Less Developed Regions/Smaller Entities: Implications for Policy in the EU", in Kubicek Herbert, Dutton William H., Williams Robin (eds.), The Social Shaping of 
Information Superhighways. European and American Roads to the Information Society, Campus Verlag, St. Martin's Press, Frankfurt/New York, 1997, pp. 277-297.

Commission of the European Communities, eEurope 2005, doc. cit.

49 See http://www.content-village.org/. A working programme for years 2003 and 2004 has been adopted last year.

50 eTen, Deploying Services for an Information Society for All (eServices), http://europa.eu.int/information_society/programmes/eten/index_en.htm

51 Commission of the European Communities, Information society Technologies. A thematic priority for Research and Development under the Specific Programme "Integrating and strengthening the European Research area" in the Community sixth Framework Programme, 2003-2004 Working programme, 2002, ftp://ftp.cordis.lu/pub/ist/docs/wp2003-04_final_en.pdf For an accurate view on societal strengths, weaknesses and challenges of each aspect of this thematic priority, see Internal Reflection Group (IRG) Report, Major Societal Challenges in the IST Programme of the Sixth Framework Programme, 8 May 2002. ftp://ftp.cordis.lu/pub/ist/docs/irg-msc-eport-v6(final).doc

As it is not the purpose of this paper, we will not emphasise international level policies and relations. But it is worth noting that agreements like WTO GATS (General Agreement on Trade in Services) as well as other multilateral or bilateral dialogue between Europe and all its partners have an important role to play in the definition of the European policies.

Six European Directives and one decision have been published in the recent times: a Framework Directive, an Access Directive, an Authorisation Directive, a Universal Service Directive, a Directive on privacy and electronic communications, and a Radio Spectrum Decision, Official Journal of the European Communities of April 24, 2002 (L108, volume 45, pp. 1-77) and July 31,2002 . Member states are awaited to have these directives transposed on national grounds not later than July 24, 2003.

As pointed out in 1999 by Catinat Michel, Entrer dans la société de l'information. L'enseignement américain, in Futuribles, Nr. 242, May 1999, pp. 19-42.

The 'Computer Systems Policy Project', an affiliation of chief executive officers of the 13 largest American computer companies, were advocating a strictly business perspective on development of the Global Information Infrastructure, together with a tough negotiating posture. FINS Special Report February 21, 1995.

New Regulatory Framework for electronic communications infrastructure and associated services, doc. cit. 
Alvaro de Miranda and Morten Kristiansen, Technological Determinism and Ideology: The European Union and the Information Society, Paper delivered at the 3rd Policy Agendas for Sustainable Technological Innovation (POSTI) International Workshop, London, U.K., 1-3 December 2000, http://www.esst.uio.no/posti/workshops/miranda.pdf

A. de Miranda et al. note that the link was first made by American presidential adviser, Zbigniew Brzezinski in his 1969 book Between Two Ages, America's Role in the Technetronic Era (quoted from A. Mattelart, Archéologie de la "Société de l'Information", in Le Monde Diplomatique, August 2000).

European Commission, White Paper on growth, competitiveness, and employment: The challenges and ways forward into the 21 st century, COM(93) 700 final, Brussels, 5 December 1993, http://europa.eu.int/en/record/white/c93700/contents.html

61 Bernard Cassen, Naissance de l'Europe S.A., in Le Monde Diplomatique, Juin 2000.

62 Volker Schneider proposes an interesting review of these hypotheses and others in: Schneider Volker, Different Roads to the Information Society? Comparing U.S. and European Approaches from a Public Policy Perspective, in Kubicek Herbert, Dutton William H., Williams Robin (eds.), The Social Shaping of Information Superhighways, opacity, pp. 339-358.

European Commission, Facing the challenge. The Lisbon strategy for growth and employment, Report from the High Level Group chaired by Wim Kok. Luxembourg: Office for Official Publications of the European Communities, 2004 - 51 pp., ISBN 92-894-7054-2

64 Ducatel Ken, Webster Juliet, Herrmann Werner, Information Infrastructures or Societies?, in Ducatel Ken, Webster Juliet, Herrmann Werner (eds.), Praise for The Information Society in Europe. Work and Life in an Age of Globalization, Rowman \& Littlefield, Lanham, 2000, p. 9. van Bastelaer Béatrice, eEurope and User Aspects of ICT, COST Working Paper No. 1, June 2001. She was research assistant at the CITA, FUNDP Namur, and is currently associate project leader at the eGovernment team of the Walloon Region, Belgium.

Although a traditional European (French?) trend of considering IT as creating more problems than it solves, we can say that EU rallied the US position which is more confident about the potential of technologies to boost growth.

67 Castells Manuel, La galaxie Internet, Fayard, Paris, 2001, 370 pp.

Wolton Dominique, Naissance de l'Europe démocratique, Champs, Flammarion, Paris, 1997, 460 pp, p. 360. Ibid., p. 373, 385.

70 Ibid., p. 381. 
71 The word 'critical mass' is taken from the conclusions of the eEurope +2003 progress report.

72 Ibid.

73 Breton, quoting Proulx. Breton Philippe, Le culte de l'Internet. Une menace pour le lien social?, La Découverte, Paris, 2000, 130 pp.

74 Schneider Volker, Different Roads to the Information Society?, op. cit., p. 340.

75 Alabau Antonio, Understanding the eGovernment Policy of the European Union. A comparative analysis with the eGovernment policies of some supranational organizations, working document, Universidad Politecnica de Valencia, Valencia, 2003.

76 Dalloz Xavier, Portnoff André-Yves, La prolifération numérique: ressorts et impacts. Repères pour "années chien"'" in Futuribles, Nr. 266, July-August 2001, pp. 23-40, p. 24.

77 Ducatel Ken, Webster Juliet, Herrmann Werner, Information Infrastructures or Societies?, op. cit. 